\title{
Globalizacija migracije i profetizam pape Franje
}

\author{
Stjepan Brebrić* \\ ks@zg.t-com.hr
}

\author{
https://doi.org/10.31192/np.17.1.6 \\ UDK: 314.151.3-054.73:272 \\ 272-732.2Franciscus, papa \\ Pregledni članak / Review \\ Primljeno: 4. prosinca 2018. \\ Prihvaćeno: 10. veljače 2019.
}

Aktualni svjetski fenomen migracija početkom trećega tisućljeća poprima takve razmjere da je opravdano govoriti o globalizaciji migracije. Izbjeglice i migranti za mnoge su lokalne političke zajednice, društva $i$ kulture izazov s kojim se ne mogu $i$ ne znaju uvijek suočiti na pravi način. Znatno bolja situacija nije niti $s$ kršćanskim i drugim religijskim zajednicama u odnosu prema ovoj problematici, a konkretna rješenja još uvijek niti u dovoljnoj mjeri niti na adekvatan način nije u stanju ponuditi međunarodna politička zajednica. O suvremenim migracijama stoga se uglavnom govori kao o migrantskoj krizi današnjice. Papa Franjo, koji je od početka svojega pontifikata duboko ganut tragedijom izbjeglica $i$ migranata naočigled ravnodušnosti pojedinaca $i$ zajednica, glasno podiže svoj proročki glas, koji prate znakovite geste $i$ konkretni prijedlozi sustavnoga $i$ programskoga prevladavanja ove krizne situacije svijeta, čije uzroke razotkriva u dubokoj antropološkoj krizi čovječanstva. Njegovo proročko tumačenje suvremenih migracija kroz koncilsku kategoriju znakova vremena prvenstveno smjera promjeni mentaliteta ljudi i zamjeni paradigme dekadentnoga humanizma paradigmom cjelovitoga $i$ kršćanski kompatibilnoga solidarnog humanizma budućnosti. Uočavajući pozitivne aspekte globalizacije migracije, potiče sve ljude na prihvaćanje i aktivno sudjelovanje u povijesnoj prilici globaliziranja bratstva, solidarnosti i ljubavi. To su općeniti okviri teološko-pastoralnih razrada pojedinačnih tema kroz koje se u ovome radu iščitavaju profetička obilježja pontifikata pape Franje u odnosu na fenomen suvremenih migracija.

Ključne riječi: profetizam pape Franje, migranti, izbjeglice, globalizacija migracije, globalizacija ljubavi, općenitija pastoralna skrb, pastoralno-humanitarna strategija.

\footnotetext{
* Dr. sc. Stjepan Brebrić, direktor i gl. urednik, Kršćanska sadašnjost, Marulićev trg 14, HR10000 Zagreb.
} 


\section{Uvod}

U današnjemu svijetu, uz sve ostale, mnogostruke i složene globalizacijske procese, naročito je prisutan općenitiji fenomen selilaštva i razmjerno najviše aktualna, konkretna globalizacija migracije. Gotovo da i ne postoje dijelovi svijeta u kojima se ne bi mogle opaziti emigracije i imigracije, progonstva i izbjeglištva, s čime su nerijetko povezani trgovina ljudima, potlačivanje i izrabljivanje pojedinih skupina u društvima i kulturama, prisilna raseljavanja pučanstva sve do nasilja nad manjinama, pa i genocidnih postupaka prema većim populacijama i čitavim narodima. To je pokazatelj duboke svjetsko-društvene i kulturalne krize, koja se, prema crkvenome učiteljstvu, teološkoj analizi i socijalnome nauku Crkve raspoznaje kao temeljna antropološka kriza.

Crkva je na Drugome vatikanskom koncilu (1962-1965) osvijestila svoju brigu i razjasnila svoj odnos prema čovjeku i svijetu, bez obzira je li pri tom riječ o kršćanima ili onima koji pripadaju različitim religijskim tradicijama i kulturama. Obnova i aktualizacija ove tematike u pojedinim je partikularnim Crkvama posebno napredovala u desetljećima nakon Koncila, a to se pod nekim vidovima, odnosno, kroz temeljna evanđeoska polazišta i teološko-pastoralne perspektive, poput preferencijalne opcije za siromašne, naročito primjećuje u Crkvama i narodima ranije nazivanog tzv. »Trećeg svijeta«, gdje najveći dio svjetske populacije živi u uvjetima krajnje oskudnosti, neimaštine i siromaštva.

Papa Franjo upoznat je upravo s problemima ljudi tih dijelova svijeta, s kojima je tijekom svojega života dijelio zajedničko iskustvo trpljenja, nepravde, ali i nade u mogućnost pravednijih međuljudskih, društvenih i ekonomskih odnosa. Sada, kao rimski biskup i poglavar Katoličke crkve podjednako je osjetljiv za probleme, ali i nade ljudi u svim dijelovima svijeta, bez obzira na mogućnosti razlikovanja svjetskih društava u kojima vlada ekonomsko blagostanje, od onih koji su u tranzicijskim procesima tek na putu prema tome cilju te onih, čije su stvarne životne okolnosti u potpunoj suprotnosti s idealom kvalitetnoga, dobroga življenja, po mjeri ljudski dostojanstvenoga života. Stoga je pun razumijevanja za riskantno poduzimanje tolikih milijuna ljudi današnjice na putu prema razvijenijim dijelovima svijeta u kojima vide bolje životne uvjete, socijalno uređena društva i veću sigurnost za vlastitu budućnost. Također je svjestan varljive stvarnosti $u$ takvim socio-ekonomski razvijenijim dijelovima svijeta, $u$ kojima mnogi ljudi žive na raznim periferijama, marginama i rubovima života. Zbog toga je neumoran u prokazivanju uzroka društvene nejednakosti, koji se strukturiraju i povećavaju nepravedne odnose među ljudima na razini cjelokupne svjetske zajednice. Pa ipak, u tim zlima današnjega svijeta, bez obzira proizlaze li iz ljudskoga srca ili su posljedica strukturalnih rasadišta kulture ravnodušnosti, isključivanja i odbacivanja najugroženijih slojeva ljudskoga društva, Papa vidi povijesnu priliku promjene paradigme dekadentnoga humanizma i nadu za osvještenjem i zajedničkim zalaganjem svih ljudi u naporu 
oko izgradnje solidarnoga humanizma koji je nužan za cjeloviti ljudski razvoj i istinski napredak čovječanstva u mirotvorstvu, bratstvu i očuvanju prirode i cjelokupnosti Božje stvorene stvarnosti.

U fenomenu suvremenih migracija, s obzirom na njegovo globalno obilježje, koje se prema mnogim pokazateljima u budućnosti čini u tom smislu još izvjesnijim, Papa proročkom smionošću ukazuje na patnje tolikih migranata i izbjeglica, a ponajprije na problem općenite ravnodušnosti i gubitka suosjećanja za te ljude u kulturalnim obilježjima današnjice, što je možda i najveća ljudska tragedija. Međutim, profetičko obilježje njegova pontifikata još je izrazitije u buđenju nade za prepoznavanje migrantske krize kao prilike za promjenu mentaliteta ljudi i očovječenje međuljudskih odnosa, što se u kontekstu njegova cjelokupnoga pristupa ovome pitanju sažeto može izreći kao takav poziv na tumačenje globalizacije migracije kroz koncilsku kategoriju znakova vremena prema kojemu je riječ o povijesnoj prilici čovječanstva za globalizaciju ljubavi. Budući da je svako proroštvo u judeo-kršćanskoj tradiciji radi izgradnje zajednice, u ovome je slučaju profetizam pape Franje podjednako dar Božji Crkvi i svijetu na putu prema izgradnji zajedništva po mjeri čovjeka stvorena na sliku Božju (usp. Post 1,27). U općoj konfuziji i nesnalaženju međunarodne i lokalnih političkih zajednica prema fenomenu suvremenih migracija, profetizam pape Franje s obzirom na globalizaciju migracije kao povijesnu priliku globalizacije ljubavi nije puko izražavanje po sebi očekivane kršćanske solidarnosti s patnicima i siromasima naših dana, nego stvaran i konkretan doprinos planiranom $i$ programskom suočavanju čovječanstva s ovom problematikom.

\section{Profetizam pape Franje}

Iako bi se o profetizmu pape Franje moglo promišljati počevši od sustavne razrade svetopisamske ili kršćansko-tradicijske teme, odnosno stvarnosti proroštva, koje je i očitim obilježjem pontifikata pape Franje, ovdje to nije slučaj. Nekoliko misli o profetizmu posve općenito, kako ga shvaćamo u katoličkoj teologiji i iskustvu kršćanske vjere, ovdje će poslužiti tek za približno pojašnjenje te stvarnosti, makar se pretpostavlja da je prilično jasno kako se, primjerice, misleći o proročkoj dimenziji pontifikata pape Franje, ne misli na profetizam toga pontifikata kao na njegovo jedino ili čak isključivo obilježje, bez obzira što je njegova naglašenost prilično raspoznatljiva. Kršćansko iskustvo profetizma zacijelo uobičajeno, o kakvome je uglavnom i ovdje riječ, čini se korisnim za razumijevanje načina na koji se papa Franjo odnosi prema problematici suvremenih migracija, što je moguće vidjeti kao svojevrsno očitovanje i potvrdu proročke dimenzije njegova pontifikata s tim u svezi. Dakako, tome uobičajenome kršćanskom iskustvu proročkoga, kao imanentnoga kršćanskoga poslanja u Crkvi i svijetu, posebno obogaćenje daje i osobno razmišljanje pape Franje o 
proroštvu, iako je nepotrebno naglašavati da je kod njega puno očitije ne samo vršenje papinske službe, nego življenje i prakticiranje kršćanske vjere u skladu s profetičkim iskustvom.

Teološka percepcija profetizma, kako u židovstvu, tako i u kršćanstvu, uglavnom se oslanja na povijest ili tradiciju starozavjetnih proroka. ${ }^{1} \mathrm{U} \mathrm{kr-}$ šćanstvu ona ima svoja razumljivo kristološka polazišta, iako je novozavjetna kristologija, ne previdjevši profetizam Isusa Krista (usp. Mt 21, 18; Mk 13, 1-2; Lk 10, 18; Iv 8, 1-11), sam naziv "prorok « smatrala nedostatnim za opis otajstva njegove bogosinovske osobe. ${ }^{2}$ Isusovo obećanje Duha Istine (usp. Iv 16, 13) već u kontekstu novozavjetne teologije profetizma naglašava pneumatološki aspekt, kako za proročko nadahnuće, tako i za njegovo tumačenje (usp. 2 Pt 1, 20-21). Općenita kršćanska percepcija profetizma u suglasju je s ovim kristološko-pneumatološkim uvidom teološke refleksije, jer samo iskustvo profetizma proizlazi iz milosnoga djelovanja Duha Svetoga u svakome kršćaninu, prethodeći racionalnom ili nekom drugom spoznajnom momentu. Drugi vatikanski koncil to iskustvo opisuje udjelom koji sveti Božji narod ima u Kristovoj proročkoj službi, a svoje proročko dostojanstvo potvrđuje svjedočenjem za Isusa Krista, za čiju je autentičnost sveukupnost vjernika obdarena nadnaravnim osjećajem vjere:

»Naime tim osjećajem vjere, koji pobuđuje i podržava Duh istine, Božji narod pod vodstvom svetoga učiteljstva, koje vjerno slijedi, prima ne više ljudsku riječ nego uistinu Božju riječ (usp. 1 Sol 2, 13), nepokolebljivo prianja uz vjeru jednom predanu svetima (Jd 3) te pravilnim sudom dublje prodire u nju i u životu je potpunije primjenjuje. $\aleph^{3}$

Unatoč proročkoj dimenziji kršćanske vjere kao takve, uz institucionalno i ministerijalno, općenitijim se čini poimanje profetizma kao osobne karizme. To ipak ne znači da su neki darovi Duha Svetoga jednima dani, a drugima uskraćeni. Sveti Pavao poziva zajednicu vjernika u Korintu da čeznu za ljubavlju i darovima Duha Svetoga, a najviše za darom proroštva, jer onaj koji prorokuje »izgrađuje, hrabri, tješi« (usp. 1 Kor 14, 3). Kao osobna karizma, profetizam je radi drugih, radi izgradnje zajednice, ili poziva ljudima na promjenu životu, na obraćenje. Nerijetko pretpostavlja i posebno Božje izabranje s određenim poslanjem i zadaćom. ${ }^{4}$ Od ljudi kojima Bog povjerava neko posebno proročko poslanje ili im, u svojoj slobodi, u izobilju daje dar proroštva, zasigurno izabire one koji su po svojoj također slobodnoj raspoloživosti otvoreniji tome daru. Neki od znakova te otvorenosti mogu se opisati na sljedeći način:

\footnotetext{
${ }_{1}$ Više o tome: Božo LUJIĆ, Starozavjetni proroci, Zagreb, 2004.

${ }^{2}$ Usp. Rino FISICHELlA, Proroštvo, u: Luciano PACOMIO, Vito MANCUSO (ur.), Enciklopedijski teološki rječnik, Zagreb, 2009, 944.

${ }^{3}$ DRUGI VATIKANSKI KONCIL, Lumen gentium. Dogmatska konstitucija o Crkvi (21.11.1964), u: Dokumenti, Zagreb, ${ }^{7} 2008$, br. $12,1$.

${ }^{4}$ Usp. Anton TAMARUT, Dom ljubavi i kršćanske radosti. Teologija i duhovnost braka $i$ obitelji, Zagreb, 2016, 92.
} 
»Prije svega, i možda pomalo ironično, biti prorok znači biti uvriježen u dijalogu - netko tko sluša, tko je pozoran, tko vidi, tko je osjetljiv za svijet, žene i muškarce. Proroci su žene i muškarci koji pažljivo osluškuju Boga, koji su u stanju prepoznati znakove vremena, koji su pozorni prema ljudskim izričajima, tonu glasa, govoru tijela. $\aleph^{5}$

Ni ove posljednje, naizgled obične, naravne ljudske predispozicije profetizma, papa Franjo ne previđa kada svojim riječima i primjerom svima upućuje poziv na praktično profetičko življenje vjere. ${ }^{6}$

Nerijetko papa Franjo i izravno potiče kršćane na profetizam. Crkvi su, prema njegovu mišljenju, danas potrebni proroci, koji - za razliku od onih koji to nisu, jer stalno kritiziraju i ni zbog čega nisu sretni - žive svoj profetizam kao molitvu, zagledanost u Boga i u njegov narod te se žaloste i plaču, ako taj narod u nečemu griješi. ${ }^{7}$ Nije to neko izvanredno vršenje proročke službe, nego redovito poslanje za koje su kršćani osposobljeni temeljnim sakramentom krštenja, kojim postaju narod Božji: »Vjeran Božji narod pomazan je milošću Duha Svetoga i zato, dok razmatramo, razmišljamo, procjenjujemo, razlučujemo, trebamo biti svjesni toga pomazanja. ${ }^{8}$ Govoreći o profetizmu redovnika, koji se po njemu nikada ne smiju odreći proroštva, što ne znači suprotstavljanje hijerarhijskome dijelu Crkve, koliko god se proročka služba i hijerarhijska struktura ne podudaraju, Papa daje svojevrsni opis profetizma:

»Biti prorok ponekad može značiti stvarati gungulu, kako se već kaže (...) Proroštvo stvara buku, viku, netko kaže 'zbrku'. Međutim, u stvarnosti njegova je karizma biti kvasac: proroštvo naviješta duh Evanđelja. « ${ }^{9}$

U drugoj prilici, na pitanje o proročkoj smionosti, papa odgovara da kod takve hrabrosti nije riječ samo o stvaranju buke, nego o tome, kako to činiti ispravno te na koji način i kada. ${ }^{10}$ I nastavlja: »A danas, više nego ikada, trebamo

${ }^{5}$ Steven B. BEVANS, Roger P. SCHROEDER, Prophetic Dialogue, New York, Maryknoll, 2011, 42.

${ }^{6} \mathrm{U}$ raznim prigodama papa Franjo podsjeća na svoje iskustvo duhovnih razgovora iz vremena koje prethodi njegovoj službi rimskoga biskupa, u kojima je na postavljena pitanja sugovornicima, gledaju li u oči osobu kojoj daju milostinju na ulici i dodirnu li ikada njezinu ruku, odgovor uglavnom bio negativan (usp. Jorge Mario BERGOGLIO, Abraham SKORKA, Marcelo FIGUEROA, Razum i vjera, dostojanstvo, molitva, solidarnost, Split, 2014, 89-90).

7 Usp. PAPA FRANCESCO, La Chiesa ha bisogno di profeti. Meditazione mattutina nella cappella della Domus Sanctae Marthae (17.04.2018); http://w2.vatican.va/content/francesco/ it/cotidie/2018/documents/papa-francesco-cotidie_20180417_lachiesa-habisogno-diprofeti. html (05.12.2018).

${ }^{8}$ Letter of His Holiness Pope Francis to Cardinal Marc Ouellet, President of the Pontifical Commission for Latin America (19.03.2016); http://w2.vatican.va/content/francesco/en/ letters/2016/documents/papa-francesco_20160319_pont-comm-america-latina.html (05.12.2018).

9 Antonio SPADARO, Razgovor s papom Franjom, Obnovljeni život, 68 (2013) 4, 437-456, 448.

${ }^{10}$ Usp. »To Have Courage and Prophetic Audacity«. Dialogue of Pope Francis with the Jesuits gathered in the 36th General Congregation (24.10.2016), http://jesuits.org/Assets/ Publications/File/GC36-Dialogue_of_Pope_Francis_ENGLISH.PDF (05.12.2018), 1. 
hrabrost i proročku smionost. Potrebna nam je parresia sadašnjosti, proročka smionost neustrašivosti. ${ }^{11}$

Malo tko se neće složiti da je isto tako malo toga u Papinim riječima i gestama što ne bi očitovalo njegovu proročku smionost. Josip Baloban primjećuje da se Papa zauzima za to »da kritičko-proročki glas povijesne Isusove Crkve ne smiju ušutkati ni ljudi unutar same Katoličke crkve ni ljudi izvan Crkve« te, istaknuvši sve one teme, pitanja i probleme današnjega čovječanstva o kojima papa Franjo neprestano proročki progovara, ustvrđuje: »Papa se pretvorio, ustvari, u neporeciv i trajno vičući glas savjesti u svijetu. ${ }^{12}$

Puno je snažnih primjera profetizma u pontifikatu pape Franje. Profetizma, kako se čini, prvenstveno radi njegove kreativnosti i znanja unošenja promjena, jer su one potrebne kako bi se kršćani prilagodili okolnostima u kojima danas trebaju naviještati evanđelje. ${ }^{13}$ Naviještati evanđelje značilo bi, prema Papi, nasljedovati Isusa Krista u današnjemu vremenu, u svijetu obilježenu mnogostrukim krizama i ljudskim tragedijama, dajući svoj doprinos preobrazbi povijesti i izgradnji kraljevstva Božjega, zalažući se za cjelovit ljudski razvoj i istinski, kršćanski humanizam. Evanđelje je svakako autentičan izvor i nadahnuće za nasljedovanje Isusa Krista. Međutim, njega možemo susretati i u raznim prigodama svoga svakodnevnog života, osobito ondje, gdje je pred nama čovjek koji pati. Među ljude, koji su danas osobito pogođeni višestruko uzrokovanim trpljenjima globalnih razmjera, papa Franjo posebno ubraja razne skupine migranata i onih koji se isključuju iz društva, pa i obitelji, govoreći o tome proročki izazovno i poučljivo:

»Kako se trebamo ponašati prema imigrantima koji prežive prijelaz preko mora i iskrcaju se na našim obalama? Što trebamo učiniti prema osamljenim, napuštenim starcima koji nemaju više nikoga? Besplatno smo primili, besplatno dajmo. Pozvani smo služiti Isusu raspetome u svakoj marginaliziranoj osobi. Dodirnuti Isusovo tijelo u onome tko je isključen, gladan, žedan, gol, utamničen, bolestan, nezaposlen, progonjen, izbjeglica. Tu nalazimo našega Boga, tu dotičemo Gospodina. Sam nam je Isus to rekao tumačeći kakav će biti protokol na temelju kojega ćemo svi biti suđeni: kad god smo to učinili jednomu od najmanje svoje braće, njemu smo učinili (usp. Mt 25, 31-46). «14

Ovo je proročki glas koji danas snažno odjekuje u svijetu koji je bez suosjećanja za tragedije i trpljenja tolikoga mnoštva ljudi koji su prisiljeni napuštati svoje domove u potrazi za sigurnijim i dostojanstvenijim životom. Svatko tko može suosjećati s njima, poistovjetiti se s tim patnicima, svjesno ili ne, nasljedu-

\footnotetext{
${ }^{11}$ Isto.

${ }^{12}$ Josip BALOBAN, Mentalni sklop pastoralnih djelatnika i pontifikat pape Franje, Bogoslovska smotra, 87 (2017) 1, 33-58, 37.

${ }^{13}$ Usp. PAPA FRANJO, Crkva milosrda, Zagreb, 2014, 31.

${ }^{14}$ PAPA FRANJO, Božje je ime milosrde. Razgovor s Andreom Torniellijem, Split, 2016, 110-111; usp. također: Jorge Mario BERGOGLIO, Abraham SKORKA, O nebu i o zemlji, Zagreb, 2013, 43.
} 
je Isusa Krista i tako poput njega proročki vrši volju Božju. A to, riječima Pape, osobito vrijedi za kršćane, također u njihovoj ekumenskoj, međureligijskoj i međukulturalnoj otvorenosti: »Kršćanstvo je iz židovske tradicije baštinilo učenje prorokâ o zaštiti siročadi, udovica i tuđinaca. $\aleph^{15}$ Papa pri tom vidi i nešto više i univerzalnije. Nasljedovati Isusa Krista u postupanju sa siromasima naših dana znači suosjećati s konkretnim čovjekom u nevolji, što je ujedno doprinos ostvarenju kraljevstva Božjega u svijetu, koje je po naravi stvari danas moguće promatrati podjednako teološki, u povijesno-eshatološkoj perspektivi, ali i društveno-antropološki, u perspektivi globalizacije solidarnoga humanizma, sveopćega bratstva ljudi, i konačno, globalizacije ljubavi. Profetički, povijesnu priliku današnjega svijeta, čini se, papa Franjo zato vidi upravo u globalizaciji migracije.

\section{Globalizacija migracije - povijesna prilika za globalizaciju ljubavi}

Pitanje suvremenih migracija toliko i na takav način obilježava pontifikat pape Franje da bi se moglo govoriti o svojevrsnom »universale concretum « proročke dimenzije njegova pontifikata. Bez obzira na naslov ovoga poglavlja, migracijska problematika općenito i migrantska kriza današnjice u profetizmu pape Franje nisu u prvome redu samo općenito pitanje selilaštva, izbjeglištva ili migracija, nego konkretni ljudi - tražitelji azila, izbjeglice, migranti i žrtve trgovine ljudima - to jest osobe za koje danas na poseban način vrijedi opredjeljenje Crkve za siromahe. Danas su oni najvidljivije žrtve globalne ekonomije isključivanja i društvene nejednakosti u suvremenome svijetu koje izravno pogađa globalizacija ravnodušnosti i kultura odbacivanja. ${ }^{16}$ Solidarnost i milosrđe stav je prema migrantima na koji papa poziva kršćansku zajednicu shvaćajući to kao revolucionarnu pokretačku snagu i doprinos zajedničkim naporima svih ljudi, svih religija, političke zajednice i civilnoga društva u suradničkoj i bratskoj humanitarnoj skrbi za one koji su prihvatili rizik puta u život dostojan čovjeka. ${ }^{17}$ Za Crkvu su migranti najočitiji znak vremena današnjice, a za čovječanstvo prilika izgradnje budućnosti mira i sveopćega bratstva, jačanja kulture susreta i integriranja, globalizacije nade i humanizma, kakvoga u ljudskoj povijesti nije bilo.

Čini se da niti u jednoj drugoj aktualnoj temi, koje također ocrtavaju proročku dimenziju pontifikata pape Franje, a koje su s ovom itekako u vezi - poput socijalne i ambijentalne ekologije, ekumenizma i međureligijskoga dijaloga

\footnotetext{
${ }^{15}$ Isto, 90.

${ }^{16}$ Usp. PAPA FRANJO, Evangelii gaudium - Radost evandelja (24.11.2013), Zagreb, 2013, br. 5354; 61-65 (dalje: EG).

${ }^{17}$ Usp. Papa Franjo, Crkva milosrda..., 24; 124-126.
} 
- ne dolazi toliko do izražaja njegov neosporan doprinos daljnjemu razvoju socijalnoga nauka Crkve, njegovo nadahnuće u teologiji naroda i društvenokulturnoj teologiji ${ }^{18}$ njegova politička teologija, ${ }^{19}$ njegova ekleziologija majčinstva Crkve u odnosu na sve ljude i misiologija Kristovih učenika misionara, ${ }^{20}$ njegova praktična duhovnost kontemplacije, razlučivanja i djelovanja, ${ }^{21}$ njegovo daljnje produbljenje koncilske kategorije znakova vremena ${ }^{22} \mathrm{i}$, iznad svega, njegova kršćanska suosjećajnost pa čak i osobna poistovjećenost s migrantima koji su podjednako u njegovu srcu i u programu njegova pontifikata. Konačno, njegov profetizam ${ }^{23}$ koji se u ovoj tematici ne ogleda samo kroz hrabrost otvorenoga i pravovremenoga govora, nego vrlo konkretnoga djelovanja s obzirom na sve i zauzimanja za sve koji su suočeni s fenomenom migracije, bilo da je riječ o migrantima bilo o onima kojima migranti stvaraju nelagodu, ali i priliku za rast u čovječnosti i za suradnju u poticanju globalizacije nade, štoviše, globalizacije ljubavi. Zbog opsežnosti ove teme, razumljivo, možemo istaknuti samo pojedine naglaske i u vezi s pojedinim pitanjima, koji se čine važni za približan uvid u njezinu cjelovitost.

Bilo bi krivo misliti da je problematici suvremenih migracija papa Franjo toliko predan jer je riječ o aktualnom svjetskom problemu. Također, razloge ne treba tražiti niti u činjenici da on sam za sebe kaže da je »dijete migranata « imigracijskoga vala 1929. godine u Argentini. ${ }^{24}$ Njegova je pastirska i profetička tankoćutnost usmjerena na svijet današnjice kao takav, a ne toliko na njegove aktualnosti kao takve, koje su drugima možda samo povod za dnevno-političke rasprave ili za stvaranje senzacija. Prije je to novo shvaćanje koncilskoga odnosa Crkve i svijeta, odgovornosti kršćana za svijet. Na pitanje o tome, koja su najgora zla današnjega svijeta, papa odgovara: »Siromaštvo, korupcija i trgovina ljudima. ${ }^{25}$ Sve troje jest problem suvremenih migracija koje su papi Franji već dugo poznate, ne samo u Europi, koja je tek odnedavno suočena s najvećom

\footnotetext{
${ }^{18}$ Više o tome: Rafael LUCIANI, Pope Francis and the Theology of the People, New York, Maryknoll, 2017; Rafael LUCIANI, Središnje mjesto naroda u društveno-kulturnoj teologiji pape Franje, Concilium, 54 (2018) 3, 63-78.

${ }^{19}$ Usp. Alessandro SANTAGATA, Pogovor, u: PAPA FRANJO, Zemlja, dom, posao. Govori na susretima pučkih pokreta, Zagreb, 2018, 125-141.

${ }^{20}$ Usp. EG, 119-120; 173.

${ }^{21}$ Vidi bilj. 52 ovog članka.

${ }^{22}$ Usp. Gustavo GUTIÉRREZ, Aparecida i povlašteno opredjeljenje za siromašne, u: Gerhard L. MÜLLER, Siromaštvo. Izazov za vjeru, Zagreb, 2015, 118-125.

${ }^{23}$ Upravo u kontekstu ove problematike Papa gotovo izravno očituje svoju profetičku dimenziju, primjerice, kada u homiliji o petoj obljetnici posjeta Lampedusi za sebe kaže »da je bio glasonoša neprolaznoga apela na čovjekovu odgovornost « prisjećajući se tada žrtava potonuća brodova (usp. PAPA FRANCESCO, Omelia per la celebrazione eucaristica per i migranti nel $V$ anniversario del Viaggio Apostolico a Lampedusa (6.7.2018.), u: isti, »Sono io, non abbiate paura «. Parole su rifugiati e migranti, Rim, 2018, 99.

${ }^{24}$ Usp. Jorge Mario BERGOGLIO, Papa Franjo odgovara. Intervjui i tiskovne konferencije, Zagreb, 2016, 374 .

${ }^{25}$ Isto, 333.
} 
migrantskom krizom u svojoj povijesti, nego na temelju prethodnoga iskustva nekih oblika najnečovječnijih emigracija u Južnoj Americi. ${ }^{26}$

Ne čudi stoga da će meksički svećenik Alejandro Solalinde - posvećen pastoralnoj i humanitarnoj skrbi migranata koje trgovci ljudima i narko-mafija iskorištavaju na razne načine, muče, ucjenjuju, siluju, prodaju njihove organe $u$ transplantacijske svrhe i u mnogim slučajevima bespoštedno ubijaju, a sve to uz šutnju i prešutno odobravanje država i političke zajednice - napose u vezi s pitanjem migracija u papi Franji vidjeti proroka koji nije povijesna slučajnost, nego Božji dar ovome vremenu, jednako za Crkvu i svijet. ${ }^{27}$ Solalindeova konstatacija da smo »svi izbjeglice«, koji su »znak vremena «, ${ }^{28}$ podudara se s Papinim mišljenjem. I tu je potrebno vidjeti kao najizrazitije istodobno evanđeoske, eklezijalne, kršćanske i humanitarne razloge Papine gotovo preferencijalne opcije za migrante, jer oni su Božji znak vremena, koji on, podsjetivši da »fenomen migracije nije istrgnut iz povijesti spasenja, već je štoviše njezin sastavni dio« (usp. Izl 22, 20; Pnz 10, 19), sažeto tumači: »Ovaj fenomen predstavlja znak vremena, znak koji govori o Božjoj providnosti na djelu u povijesti i u ljudskoj zajednici, s obzirom na opće zajedništvo. ${ }^{29}$ Migracije su prepoznate u Crkvi kroz kategoriju znakova vremena i ranije, primjerice, u Poruci za Svjetski dan selilaca $i$ izbjeglica 2006. Benedikta XVI., ali su neprevidivi doprinosi koje u novome produbljenju značenja toga znaka vremena za Crkvu i svijet današnjice daje upravo papa Franjo, polazeći već od samoga shvaćanja uzroka i posljedica migracija prema daljnjoj razradi i poticajima, kako u teološko-pastoralnoj, tako i u društveno-kulturalnoj perspektivi globalizacije suradnje, solidarnosti i ljubavi.

\subsection{Između ravnodušnosti i suosjećanja}

Na manjak solidarnosti i globaliziranu ravnodušnost u svijetu papa Franjo znakovito ukazuje upravo na svojemu prvom putovanju, 8. srpnja 2013., na Lampedusi, gdje su tako očiti drama izbjeglištva, nesnalaženje i nemoć Europe i međunarodne zajednice, a iznad svega, pomanjkanje podjednako kršćanskoga i ljudskoga suosjećanja te socijalne raspoloživosti za humano prihvaćanje i zbrinjavanje izbjeglica i migranata. Za kršćane stav gostoprimstva prema strancima, progonjenima, emigrantima svetopisamski je jasan i nedvosmislen (usp. Post 18, 1-15; Iz 58, 7; Mudr 19, 13-17; Mt 25, 35; Rim 12, 13; Heb 13, 2). Zato papa Franjo, svjestan različitih stajališta o prihvatu imigranata i među

\footnotetext{
${ }^{26}$ Više o tome: Alejandro SOLALINDE, Lucia CAPUZZI, Narkodileri me žele ubiti. Meksiko, svećenik u borbi protiv trgovine ljudima, Zagreb, 2018.

${ }^{27}$ Usp. isto, 150.

${ }^{28}$ Usp. isto, 157.

${ }^{29}$ PAPA FRANCESCO, Messaggio per la Giornata Mondiale del Migrante e del Rifugiato 2017 (15.1.2017.), u: isti, »Sono io...«, 55.
} 
europskim kršćanima, podsjeća na prvo pitanje u Bibliji, koje se odnosi na Adamovu izgubljenost nakon grijeha (usp. Post 3, 9), a zatim proročki svima upućuje drugo Božje pitanje, koje također stoji na početku biblijske povijesti: »Kajine, gdje je tvoj brat?« (Post 4, 9) i nastavlja:

»Ova dva Božja pitanja odjekuju i danas, svom svojom snagom! Mnogi su od nas, tu uključujem i sebe, izgubljeni, nismo više pozorni prema svijetu u kojemu živimo, ne brinemo se, ne čuvamo ono što je Bog stvorio za sve ljude, i nismo više sposobni paziti jedni na druge.. ${ }^{30}$

Papa aktualizira riječ Božju upućenu čovjeku u obliku dvaju pitanja koja su u vezi s njegovim iskrivljenim odnosom prema Bogu i braći ljudima kroz svu povijest. Ta je riječ konkretizirana u vezi s tragedijom tolikih desetaka tisuća migranata koji su stradali na putu iz Afrike prema Italiji, ali ona je općenita i tiče se svih ljudi. Stoga je papi Franji posebno važna kao stalni naglasak proročke dimenzije njegova pontifikata:

$» U$ prvim godinama svoga pontifikata opetovano sam izražavao posebnu zabrinutost zbog žalosne situacije mnogih migranata i izbjeglica koji bježe od rata, progona, prirodnih katastrofa i siromaštva. Ta je situacija nesumnjivo 'znak vremena', koji sam se trudio tumačiti, uz pomoć Duha Svetoga, još od svoga posjeta Lampedusi... «11

Za one, koji u Papinu gorljivu zauzimanju za human prihvat migranata ne razaznaju cjelovitu viziju, njegove se riječi, geste i konkretni pastoralni i društveno-politički prijedlozi mogu činiti trenutno dopadljivom pobožnošću usmjerenom na jedno prolazno pitanje, ili pak utopijom. Nema sumnje da je on posebno pogođen i izazvan stradanjima migranata, trpljenjem i tragedijom tih ljudi. No jednako tako, poput mnogih biblijskih proroka, i on je prvenstveno ražalošćen zbog zatvorena i okorjela srca današnjih ljudi, među kojima i kršćana, a čini se, osobito katolika. Za papu Franju vrijedi ono što Walter Kasper kao problem današnjega svijeta ističe o pitanju azila i imigracije kao konkretnome primjeru: »Bez milosrđa nove se nevolje uopće ne mogu otkriti.«32 Milosrđe je dublje, teologalno kreposno odnošenje kršćana prema ljudima i stvorenome svijetu, ali ono što je potrebno svim ljudima, i na čemu Papa stalno inzistira, jest osjećaj solidarnosti i suosjećanja jednih prema drugima, a to danas posebno vrijedi za izbjeglice i migrante. Suprotan tome je stav indiferentnosti, koji papa, zanimljivo, u svojoj apostolskoj pobudnici Evangelii gaudium spominje četiri puta, od čega dva puta u kontekstu ekonomije i dva puta u vezi s općom kultu-

\footnotetext{
${ }^{30}$ Papina homilija na Lampedusi (8.7.2013.), u: http://www.zg-nadbiskupija.hr/print. aspx?id=7544 (9.10.2018.).

${ }^{31}$ PAPA FRANCESCO, Messaggio per la Giornata Mondiale del Migrante e del Rifugiato 2018 (14.1.2018.), u: isti, »Sono io...«, 81.

${ }^{32}$ Walter KASPER, Milosrđe. Temeljni pojam evanđelja - ključ kršćanskoga života, Zagreb, 2015, 246.
} 
rom. ${ }^{33}$ Stvarnosti ekonomije i kulture, na žalost, povezane su ravnodušnošću čovječanstva za one koji su najpotrebniji njihove solidarnosti i suosjećanja. U pitanju globalizacije migracije, kao svjetske tragedije i ljudske, ali i kršćanske zatečenosti njome, indikativan je komentar njegove homilije na Lampedusi:

»U svojoj mučnoj propovijedi, doveo je u pitanje globalizaciju indiferentnosti te je pozvao na obnovu sposobnosti jadikovanja nad patnjom drugih. Stoga je on učinio Lampedusu granicom između indiferentnosti i suosjećanja. « ${ }^{34}$

Papa je duboko potresen patnjom i stradanjem izbjeglica i migranata, ali još više - i to je cjelovita slika koju treba vidjeti - patnjom i stradanjem koje se tiče svih ljudi, jer su izgubili osjećaj solidarnosti i suosjećanja jedni prema drugima, a kršćani današnjice premalo se otvaraju Božjemu daru milosti, nedovoljno živeći i očitujući bogočovječno milosrđe među sobom, u odnosu na sve ljude i svijet. Zato je izazov migrantske krize i globalizacija migracije prigoda za obnovu odnosa čovjeka s Bogom i braćom ljudima i možda jedinstvena prilika za pravi mir i sveopće bratstvo.

\subsection{Tko su zapravo migranti?}

Na pitanje, tko su migranti, papa Franjo odgovara:

»Migranti su naša braća i sestre u potrazi za boljim životom, daleko od siromaštva, gladi, izrabljivanja i nepravedne raspodjele dobara našeg planeta, koja bi svi trebali ravnopravno dijeliti. Nije li možda želja svakog čovjeka da živi bolje i uživa pristojno blagostanje koje će dijeliti sa svojim dragima? «35

Papa dobro razlikuje kategorije tih ljudi u potrazi za većom sigurnošću i dostojanstvenim življenjem - tražitelji azila, izbjeglice, migranti, žrtve progona ljudima - ali njihova kategorizacija u nekim državnim politikama, kao i u općenitoj percepciji društva, ne smije biti razlog za njihovo odbacivanje i neprihvaćanje zbog pogrešnih stavova:

»U mnogim odredišnim zemljama uzela je velikog maha retorika u kojoj se ističu opasnosti za nacionalnu sigurnost ili visoki troškovi primanja novih pridošlica, iskazujući time prezir prema ljudskom dostojanstvu koje se mora priznati svima kao Božjim sinovima i kćerima. Svi koji, možda i zbog političkih razloga, namjesto da grade mir raspiruju strah od migranata, siju nasilje, rasnu diskriminaciju i ksenofobiju, što izaziva veliku zabrinutost kod svih onih kojima je na srcu sigurnost svakog čovjeka.«36

\footnotetext{
${ }^{33}$ Usp. Dennis KIM, Papa na granici, Concilium, 51 (2015) 3, 139-145, 143.

${ }^{34}$ Isto, 142.

${ }^{35}$ PAPA FRANCESCO, Messaggio per la Giornata Mondiale del Migrante e del Rifugiato 2016 (17.1.2016.), u: isti, »Sono io...«, 44.

${ }^{36}$ PAPA FRANCESCO, Messaggio per la 51 Giornata Mondiale della Pace (01.1.2018.), u: isti, »Sono io...", 72-73; usp. također: PAPA FRANCESCO, Discorso ai direttori nazionali della
} 
Migranti su siromasi koje se nemilosrdno gazi, a za one koji to čine, opomena proroka Amosa (usp. Am 8, 4.11) danas je posebno aktualna, jer te malene koje se satire kao »žrtve one kulture odbacivanja koja je više puta prokazana" papa Franjo prepoznaje danas i u migrantima i izbjeglicama. ${ }^{37}$ Stranci, migranti, izbjeglice, prognanici i tražitelji azila koji kucaju na naša vrata, na vrata novih zemalja u koje dolaze, prigoda su za susret s Isusom Kristom koji se poistovjećuje i s prihvaćenima i s odbačenima svakoga doba (usp. Mt 25, 35-43), to je zajednička prigoda za susret s Isusom Kristom lokalnih zajednica i pridošlica, a susret $\mathrm{s}$ njim uvijek je iskustvo spasenja. ${ }^{38}$ Mnogostruki uzroci migracija rat, glad, diskriminacija, progonstvo, siromaštvo, devastacija okoliša - imaju za posljedicu u novije vrijeme 250 milijuna migranata, od čega 22,5 milijuna izbjeglica u potrazi za boljim uvjetima života, pri čemu, nažalost, nailaze na ograde i zidove. ${ }^{39}$ Neprihvaćanje i neprijateljstva posebno pogađaju djecu, žene i starije osobe među migrantima, ali može li se okamenjeno srce pokrenuti nad trpljenjem tako ranjivih skupina u društvu, a ne samo među migracijskom populacijom, kada se, prema papi Franji, o izgnanicima, koje naziva »skrivenim izgnanicima«, misleći pritom na starije osobe, kao s takvima nerijetko postupa i u obiteljima naših razvijenih društava? ${ }^{40}$

\subsection{Izazovi migracija za Crkvu i kršćanske zajednice}

Od općenitijega shvaćanja migracija, koje su početkom ovoga tisućljeća globalan fenomen, jer zapravo obuhvaćaju sve dijelove svijeta, posebno su važna Papina promišljanja i prijedlozi vezani uz migracijska kretanja kao izazove za Crkvu i kršćansku zajednicu. On ističe potrebu ne neke nove ekleziologije, nego aktualizaciju pa i radikalizaciju ekleziologije utemeljene u kerigmatskoj kristologiji, kao najviše primjerene ovome povijesnom trenutku:

»Crkva bez granica, majka svim ljudima, širi u svijetu kulturu prihvaćanja i solidarnosti, prema kojoj se nikoga ne treba smatrati beskorisnim, nepoželjnim ili odbačenim. Kada doista živi svoje majčinstvo, kršćanska zajednica hrani, usmjerava i pokazuje put, strpljivo prati, postaje bliska u molitvi i djelima milosrđa. «1

Pastorale per i Migranti partecipanti allincontro promosso dal Consiglio delle Conferenze Episcopali d'Europa (CCEE) (22.9.2017.), u: isti, »Sono io...«, 22-23.

${ }^{37}$ Usp. PAPA FRANCESCO, Omelia per la celebrazione eucaristica per i migranti nel $V$ anniversario del Viaggio Apostolico a Lampedusa (6.7.2018.), u: isti, »Sono io...«, 99.

${ }^{38}$ Usp. PAPA FRANCESCO, Omelia per la celebrazione eucaristica nella Giornata Mondiale del Migrante e del Rifugiato (14.1.2018.), u: isti, „Sono io..." «, 93-94.

${ }^{39}$ Usp. PAPA FRANCESCO, Messaggio per la 51 Giornata Mondiale della Pace (1.1.2018.), u: isti, »Sono io...«, 69-70.

${ }^{40}$ Usp. PAPA FRANJO, Bog je ondje gdje čovjek doživljava progon, odbacivanje i napuštenost (29.12.2013); http://www.zg-nadbiskupija.hr/print.aspx?id=9540 (29.11.2018).

${ }^{41}$ PAPA FRANCESCO, Messaggio per la Giornata Mondiale del Migrante e del Rifugiato 2015 (18.1.2015.), u: isti, »Sono io...«, 35. 
Slijedeći primjer Isusa Krista, kršćani ne mogu drukčije odgovoriti na probleme migranata nego milosrđem, u teološkom i socijalnom vidu. Oni su najpozvaniji pratiti migrante na njihovu putu, na kojemu se susreću s lokalnim crkvenim zajednicama, također nastojati shvatiti uzroke migracija, što jest važno, kao i založenost u prevladavanju negativnih učinaka migracijske pojave i prepoznavanje vrijednosti njezinih pozitivnih utjecaja na zajednice podrijetla, tranzita i odredišta migracijskih kretanja. Ali najvažniji doprinos kršćana prevladavanju migrantske krize ipak je u isticanju prvenstva i dostojanstva ljudske osobe (usp. Post 1, 26-27), u priznavanju toga dostojanstva svakome strancu, izbjeglici i migrantu, kao i u s tim povezanim teološkim razumijevanjem svih ljudi kao djece Božje, bez obzira na sve različitosti među njima. Papa to glasno izriče:

»Svako je ljudsko biće Božje dijete! U njemu je utisnuta Kristova slika! Mi sami moramo prvi gledati i pomoći drugima vidjeti u seliocima i izbjeglicama ne samo problem koji treba riješiti, već brata i sestru koje treba prihvatiti, poštivati i ljubiti. Oni su prigoda koju nam pruža providnost da pridonesemo izgradnji pravednijega društva, savršenije demokracije, solidarnije zemlje, svijeta u kojem će vladati veće bratstvo kao i otvorenije i evanđeoske kršćanske zajednice. Migracija može pružiti mogućnost nove evangelizacije, stvoriti prostore za rast novog čovječanstva predoznačenog $\mathrm{u}$ vazmenom otajstvu - čovječanstva za koje je svaka strana zemlja domovina, a svaka domovina tuđina.« ${ }^{42}$

Za Papu je izazov migracije prigoda kršćanskoj zajednici u njezinu evanđeoskom, eklezijalnom pa i humanom rastu. Kršćani se u posebnoj skrbi za migrante mogu svijetu očitovati kao kvasac, sol zemlje $i$ svjetlo svijeta, kao znak nade novoga humanizma koji ne poznaje granice niti razlike među ljudskim bićima. Promatran u ekleziološkoj perspektivi, odnos prema migrantima prigoda je za bolje shvaćanje kršćanstva i življenje evanđeoskoga, koncilskoga katoličanstva, ali i na eklezijalnoj, pastoralnoj i duhovnoj razini Papa vrijednim primjećuje da su »posljednjih godina mnoge partikularne Crkve u Europi obogaćene prisutnošću katoličkih migranata, koji su donijeli svoje pobožnosti i svoje liturgijsko i apostolsko oduševljenje i entuzijazam « ${ }^{43} \mathrm{Uz}$ to, kao pozitivno u migracijama ne propušta iz misiološke perspektive istaknuti da

»suvremeni migracijski valovi čine novu misijsku 'granicu', povlaštenu priliku za naviještanje Isusa Krista i njegova evanđelja bez izlaženja iz vlastitoga okru-

${ }^{42}$ PAPA FRANCESCO, Messaggio per la Giornata Mondiale del Migrante e del Rifugiato 2014 (19.1.2014.), u: isti, »Sono io...«, 30.

${ }^{43}$ PAPA FRANCESCO, Discorso ai direttori nazionali della Pastorale per i Migranti partecipanti allincontro promosso dal Consiglio delle Conferenze Episcopali d'Europa (CCEE) (22.9.2017.), 66. Papa Franjo, u perspektivi teologije naroda, nerijetko kao posebno obogaćenje pridošlica u susretu s kršćanskim zajednicama sredina svojih odredišta ističe vrijednost njihove "pučke duhovnosti«, koju pod tim izrazom tumači kao poseban doprinos Aparecide ranijemu govoru učiteljstva najprije o "pučkoj religioznosti« i potom o "pučkoj pobožnosti« (usp. Jorge M. BERGOGLIO, Prefazione, u: Enrique Ciro BIANCHI, Introduzione alla teologia del popolo. Profilo spirituale e teologico di Rafael Tello, Bologna, 2012, 15). 
ženja, za konkretno svjedočenje kršćanske vjere i ljubavi u dubokom poštivanju prema drugim religijskim izrazima«,

što također u susretu s migrantima i izbjeglicama drugih konfesija i religija znači »plodno tlo za razvoj iskrenog i obogaćujućeg ekumenskog i međureligijskog dijaloga «. ${ }^{44}$ Konkretizacija profetizma pape Franje upravo u vezi s fenomenom migracija uočljiva je u njegovu dvostrukome pozivu partikularnim Crkvama da podižu svoj »blagovremeni i proročki glas« kojemu bi trebao prethoditi »dosljedan rad nadahnut načelima kršćanskoga učenja« ${ }^{45}$ Uočljiv je kod toga i općenit poziv na obnovu ekleziologije, u kojoj je naglasak na Crkvi otvorenoj svima i na njezinoj misijskoj usmjerenosti u kojoj je svaki njezin član Kristov učenik misionar, ali iznad svega, poziv na kršćanski humanizam koji u današnjemu svijetu treba prednjačiti u kulturi susreta i prihvaćanja, nasuprot kulturi odbacivanja i isključivanja. Zbog toga su važne teološko-eklezijalne pastoralne smjernice, svojevrstan program djelovanja, ali i općenitija pastoralna $s k r b^{46}$ za ljude pogođene migracijama, što je zapravo programatski prijedlog upućen jednako Crkvi, međunarodnim i lokalnim političkim zajednicama, humanitarnim organizacijama i civilnome društvu zemalja migracijskih tranzita i imigracijskih odredišta.

\subsection{Globalna pastoralno-humanitarna strategija}

Prema riječima o. Michaela Czernyja, podtajnika Odjela za migrante i izbjeglice »Dikasterija za promicanje cjelovitog ljudskog razvoja» - koji je s radom započeo 1. siječnja 2017. godine i čiji je odjel za izbjeglice i migrante ad tempus pod izravnom ingerencijom Pape $^{47}$ - naučavanje pape Franje u ovome pitanju je »mnogo više od jednostavnog 'pustite ih da uđu', koji je oprečan onome 'ostavite ih vani'«, jer ono »pruža temeljit i istodobno praktičan vodič za djelotvorno suosjećanje« i u tom smislu njegov »odgovor na tražitelje azila i ranjive migrante izražava se u četiri aktivna glagola, četiri djelatnosti koje treba učiniti i nastaviti činiti na svim razinama: primiti, zaštititi, promicati $i$ integrirati«. ${ }^{48}$ Papa

\footnotetext{
${ }^{44}$ Usp. PAPA FRANCESCO, Discorso ai direttori nazionali della Pastorale per i Migranti partecipanti all'incontro promosso dal Consiglio delle Conferenze Episcopali d'Europa (CCEE) (22.9.2017.), 65.

${ }^{45}$ Isto, 67. Papin poziv nailazi na odjek u našoj partikularnoj Crkvi, o čemu svjedoči prošlogodišnja analitička i programatska izjava Komisije »Pravda i mir« HBK-e, u kojoj se posebno vodi računa o fenomenu migracija i izbjeglištva u nama odgovarajućem nacionalnom i europskom kontekstu [usp. HRVATSKA BISKUPSKA KONFERENCIJA, Izazovi migrantske krize u europskom prostoru (17.07.2018); http://www.hbk.hr/?type=vijest\&ID=701 (05.12.2018)].

${ }^{46}$ Usp. PAPA FRANCESCO, Messaggio per la 51 Giornata Mondiale della Pace (1.1.2018.), isti, »Sono io...«, 79.

${ }^{47}$ Usp. POPE FRANCIS, Statutes of the Dicastery for Promoting Integral Human Development, čl. 1, $\mathbb{\$} 4$; http://w2.vatican.va/content/francesco/en/motu_proprio/documents/papafrancesco_20160817_statuto-dicasterio-servizio-umano-integrale.html (05.12.2018).

${ }^{48}$ Michael CZERNY, Introduzione, u: Papa Francesco, »Sono io...«, 14.
} 
je u više prigoda predlagao i detaljno tumačio ovu prilično sustavnu strategiju, kadru tražiteljima azila, izbjeglicama, migrantima i žrtvama trgovine ljudima omogućiti priliku na njihovu putu prema boljemu životu, a koja u sebi objedinjuje četiri djelovanja - primiti, zaštititi, promicati $i$ integrirati. Posebno u svojoj Poruci za Svjetski dan selilaca i izbjeglica 2018. i u Poruci za svjetski dan mira iste godine. Ta je strategija istovremeno razrađena $\mathrm{u} »$ Dvadeset točaka pastoralnog djelovanja ${ }^{49}$ kao prijedlog onoga što mogu učiniti mjesne Crkve, župe, katoličke udruge, udruženja građana i pojedinci kako bi osobno i praktično, duhovno i institucionalno pružili svoju pomoć migrantima i izbjeglicama, a tih je 20 točaka akcijskoga plana također prerečeno političkim jezikom, i kao takve one su izravan doprinos Crkve dvama svjetskim sporazumima Ujedinjenih naroda o izbjeglicama, i za sigurnu, reguliranu i zakonitu migraciju. ${ }^{50}$

Ovako sustavna i ujedno konkretna strategija nesumnjiv je doprinos pape Franje aktualnom razvoju socijalnoga nauka Crkve, što ujedno znači i višestruke izazove za kršćanstvo, kako ad intra, tako i ad extra. Primjerice, kard. Gerhard L. Müller u problematici izbjeglištva i siromaštva vidi otvaranje kršćanstva, ali i europske teologije 21. stoljeća za nove aktualne teme i pitanja, što se može shvatiti kao:

»Nužna reakcija na promjene - koje se ocrtavaju, a ponekad su veći opipljive - u politici, društvu i privredi, u zapažanju - koje se promiče - kulturne i etničke pluralnosti, koje će imati nedogledne posljedice za Europu, taj sistem svjetova i kultura koji je do sada bio (gotovo) zatvoren.$^{51}$

Očito, i u svjetlu današnjih migracija kao svjetskoga fenomena, ne možemo previdjeti važnost i značenje koje crpeći iz svojega pastoralnog iskustva, teologije naroda i društveno-kulturne teologije, a na poseban način iz kontemplativno-praktične, ekumenske, međureligijski i međukulturalno dijaloške te socijalno-politički i ekološki angažirane duhovnosti razlučivanja, prosudbe i djelovanja, naročito aktualne $u$ ovome povijesnom trenutku, ${ }^{52} \mathrm{u}$ obliku jasne

${ }^{49}$ Usp. $» 20$ Punti di Azione Pastorale«; http://migrants-refugees.va/it/20-punti-dazione (05.12.2018).

${ }^{50}$ Riječ je o sporazumu pod općim nazivom »Global Compact«, koji neki umjesto »sporazuma« radije nazivaju »katalogom mjera«. Kao medijski općenitiji, koristi se naziv. »Marakeški sporazum« (Marakeš, Maroko). Globalni kompakt UN-a izrađen je u srpnju 2018. u skladu s »Deklaracijom o izbjeglicama i migrantima «, a države članice, koje su to htjele, prihvatile su ga u prosincu iste godine u Marakešu [usp. Global Compact for safe, orderly and regular migration; https://www.tportal.hr/media/file/4ca2514f1996d4a20864809ee888672 (15.12.2018)].

${ }^{51}$ Gerhard L. MÜLLER, Soteriologija i etika. Siromaštvo kao izazov za Crkvu, Communio, 41 (2015) 122, 81-85, 83.

${ }^{52}$ Više o tome: Anđelko DOMAZET, Kršćanska duhovnost u ozračju pluralizma, Crkva u svijetu, 38 (2003) 1, 41-73, osobito 63-68. Iako se nadahnuća za to nalaze i u socijalnom nauku Crkve (usp. PAPINSKO VIJEĆE »IUSTITIA ET PAX«, Kompendij socijalnog nauka Crkve, Zagreb, 2005, br. 9; 161), a Papa govori o »evanđeoskom razlučivanju« kao »pristupu učenika misionara« (usp. EG 50), aludirajući na ignacijevsku duhovnost kard. Kasper primjećuje da »papa Franjo kao isusovac razmatra konkretnu situaciju i do prosudbe dolazi putem duhovnoga razlučivanja « (Walter KASPER, Ein Jahr Pontifikat Papst Franziskus; http://kardinal-kasper-stiftung. 
orijentacije u raspoznavanju i tumačenju znakova vremena, kao i konkretnoga načina zauzimanja za one najpotrebitije među nama, danas pruža proročki glas pape Franje. Pri tom se posebno važnom čini, vezano uz globalizaciju migracije, njegova općenitija pastoralna skrb, što je i svojevrstan društveno-kulturalni i socijalno-politički doprinos snalaženju čovječanstva u epohi globalizacije migracije kao povijesnoj prilici za globalizaciju nade, solidarnosti i ljubavi, ${ }^{53}$ samo ako se prihvati njegovo - $\mathrm{u}$ kršćanskome socijalnom nauku posve utemeljeno - inzistiranje na tome, da je osoba u središtu kršćanskoga opredjeljenja i da je stoga osobna sigurnost ispred nacionalne ${ }^{54}$ te ako se ovi smjerokazi, koji za čovječanstvo današnjice dolaze iz kršćanstva, shvate utoliko vjerodostojnima i stoga prihvatljivima, ukoliko i sami kršćani, poglavito katolici, prevladaju religiozno i kulturno začahurivanje ${ }^{55}$ i tamo gdje su u mogućnosti, ne odbace Krista u strancu koji pokuca na njihova vrata uz izgovor neodređene moralne dužnosti obrane svoje vjere $i$ identiteta. ${ }^{56}$

\section{Zaključak}

Globalni fenomen migracija moguć je pokazatelj započete promjene epohe čovječanstva u kojoj kršćani trebaju - zajedno sa svima drugima, napose vjernicima i humanistima - na svim lokalnim i međunarodnim razinama crkvenoga, društveno-političkoga i kulturalnoga života, promicati ideju sveopćega bratstva i graditi budućnost trajnoga mira i blagostanja, globalizirajući milosrđe i ljubav kao autentično nasljedovanje povijesti i života Isusa Krista u njegovoj objavi kraljevstva Božjega. To je kršćanska odgovornost ovdje i sada. Profetizam pape Franje Božji je dar našemu trenutku povijesti, da bismo tu odgovornost znali i mogli ozbiljnije prihvatiti i svojim životom potvrditi.

Taj dar, tako jasno očitovan u profetičkome odnosu pape Franje prema problematici suvremenih migracija, podjednako je izazovan za kršćane, religije i kulture, međunarodne i lokalne političke zajednice te za sve ljude. To je Božji milosni dar ljudima današnjice. Dar nadnaravne milosti, ali i one općenite,

de/documents/EinJahrPontifikatPapstFranziskus_000.pdf (21.11.2018). O »razlučivanju « kao glavnoj točki ignacijevske duhovnosti (usp. IGNACIJE LOYOLSKI, Načela duhovnosti. Duhovne vježbe - Pravila za raspoznavanje duhova), Split, 2016, 178-184) koja mu pomaže u papinskoj službi, papa Franjo očituje se u razgovoru, u kojemu sugovornik stoga primjećuje: »Razlučivanje je, dakle, stup Papine duhovnosti« (Spadaro, Razgovor s papom Franjom..., 441).

${ }^{53}$ Usp. PAPA FRANCESCO, Messaggio per la Giornata Mondiale del Migrante e del Rifugiato 2015 (18.1.2015.), u: isti, »Sono io...«, 39.

${ }^{54}$ Usp. PAPA FRANCESCO, Messaggio per la Giornata Mondiale del Migrante e del Rifugiato 2018 (18.1.2018.), u: isti, »Sono io...«, 84.

${ }^{55}$ Usp. PAPA FRANCESCO, Discorso ai direttori nazionali della Pastorale per i Migranti partecipanti all'incontro promosso dal Consiglio delle Conferenze Episcopali d'Europa (CCEE) (22.09.2017), 63.

${ }^{56}$ Usp. isto. 
naravne, kojom je svaki čovjek u ovome povijesnome trenutku u procesima globalizacije migracija Božjim (su)djelovanjem u povijesti spasenja pokrenut, potpomognut i ohrabren doprinositi pojedinačno i u raznim oblicima zajedništva ostvarenju proročke vizije pape Franje o globalizaciji ljubavi.

To je ujedno i plan povijesno-eshatološkoga ostvarenja kraljevstva Božjega, koji je svim ljudima, bez obzira na svjetonazorski pluralizam, prepoznatljiv u različitosti percepcija, ali također u mogućnosti jedinstvenoga osvještenja i razumijevanja nužne promjene nepravednih društveno-kulturalnih, političkoekonomskih i drugih odnosa u svijetu, među ljudima i stvorenim stvarnostima, a ponajviše kao neodgodiva potreba prevladavanja dekadentnoga humanizma današnjice cjelovitim, integralnim, istinskim i kršćanski kompatibilnim humanizmom budućnosti. Sve to na neki način razvidno je u pozadini i smjerodavnosti profetičkoga zalaganja pape Franje u obziru prema izazovima današnjega globalnoga fenomena migracija, kako za kršćane, tako i za cjelokupno čovječanstvo.

U tom smislu migracije su aktualan znak vremena koji inkarnacijskom logikom očituje Božju uvijek djelatnu prisutnost u povijesti, a papa Franjo, u skladu $\mathrm{s}$ koncilskim i aktualiziranim shvaćanjem kategorije znakova vremena, $\mathrm{u}$ tome proročki vidi ono što vjeruje da se događa i da će biti, jer je to Božja volja i božanski naum iz kojega nitko nije isključen, osim svojevoljno, zbog čega i jest toliko važno proročko naviještanje evanđelja i promicanje autentičnoga humanizma, jer nada u Božju vjernost i naklonost prema svojemu stvorenju ne može iščeznuti unatoč svim razočaranjima čovječanstva ovoga svijeta. 


\section{Stjepan Brebrić* \\ The Globalisation of Migration and the Prophetism of Pope Francis}

Summary

The current global phenomenon of migration at the beginning of the third millennium is gaining such a momentum that it would be justifiable to talk about the globalisation of migration. For many local political communities, societies, and cultures refugees and migrants are a challenge that they often cannot or do not know how to deal with in a proper way. Christian and other religious communities are also not doing much better when it comes to this issue, while the international political community has not offered so far concrete solutions that would address the issue adequately and integrally. Therefore, contemporary migrations are usually addressed as the current migration crisis. From the beginning of his pontificate Pope Francis has been deeply moved by the tragedy that besets refugees and migrants and that is seemingly ignored by individuals and communities. He has raised his prophetic voice and followed it by significant gestures and concrete proposals on how to overcome this crisis situation, whose causes he detected in the deep anthropological crisis, systematically and programmatically. His prophetic interpretation of contemporary migrations through the conciliar category of signs of the times aims at a transformation of the mentality of people and a replacement of the paradigm of decadent humanism with the paradigm of integral and solidary humanism of the future, compatible with Christianity. While noticing positive aspects of the globalisation of migration, Pope Francis has encouraged everyone to accept and actively participate in this historical chance of globalisation of brotherhood, solidarity, and love. The aforementioned is the general framework of theological-pastoral analyses of individual topics through which this contribution is detecting prophetic characteristics of the pontificate of Pope Francis in relation to the phenomenon of contemporary migrations.

Key words: prophetism of Pope Francis, migrants, refugees, globalisation of migration, globalisation of love, general pastoral care, pastoral-humanitarian strategy.

(na engl. prev. Nenad Polgar)

\footnotetext{
* Stjepan Brebrić, PhD, Director and Editor-in-Chief, Kršćanska sadašnjost; Address: Marulićev trg 14, HR-10000 Zagreb, Croatia; E-mail: ks@zg.t-com.hr.
} 